\title{
DISAPPEARANCE OF THE PEREGRINE FALCON AS A BREEDING BIRD IN A RIVER VALLEY* IN ALBERTA
}

\author{
by Dick Dekker, 10944 - 71 Avenue, Edmonton
}

The following data on the breeding of the Peregrine Falcon (Falco peregrinus) along a certain river in Alberta are far from complete and refer only to a stretch of approximately 25 miles. Along this stretch in 1960 there were five cliffs, each occupied by a breeding pair of Peregrines, and one cliff occupied by a single male. By 1965 this population had dwindled to two breeding pairs, and the following year only one pair remained. In 1967 this last pair returned to its traditional cliff but the male disappeared early in the courtship period. The female, apparently unable to find a new mate, deserted soon after. The Peregrine has ceased to exist as a breeding bird in this area.

I do not know to what extent the population decline of these falcons was effected by pesticide residues, which are believed to prevent the birds from breeding normally. During the last years their breeding behaviour appeared normal and young were produced. This however, does not prove that these falcons were free from pesticide residues. Cade (1967) has found rather high levels of residues of chlorinated hydrocarbons in the eggs and tissues of falcons along the Yukon River, which did not seem to interfere with a normal rate of reproduction.

In the years of population decline along this Alberta river the falcons were subject to much interference by humans. Young Peregrines have been found shot. In 1965 and 1966 the young of at least two eyries were robbed by falconers from British Columbia. They had approached a well-known Alberta naturalist who many years ago had written about the Peregrines of this particular river.

* For reasons obvious later in this article I prefer not to give the name of this river valley.
Under the false pretence of bird study, the falconers learned about the exact location of the birds. It is reported that they took nine young falcons (of which several may have been Prairie Falcons) in 1965. The number taken in later years is unknown. There is also good reason to believe that a professional animal dealer, who lives in Alberta, has travelled down this river (as well as other rivers) with the special purpose of securing Peregrines and selling them to falconers. Herbert and Herbert (1965) have mentioned the detrimental actions of falconers along the Hudson River. Maurice Broun (1966) recently wrote about the extensive illegal trade in Peregrines and other birds of prey in the U.S.

The population decline of Peregrine Falcons in many parts of the U.S. and Canada may indeed be blamed in part on falconers. They are a highly mobile and dedicated group; not many eyries in accessible areas have escaped their continued attention. Recently their radius of action has been extended northward to include rivers in the Yukon and in the Northwest Territories.

As some falconers are quick to point out, disturbances by birdwatchers and photographers may have been another cause of the destruction or desertion of nests. I would like to mention that I have refrained from climbing to Peregrine eyries since 1961. I have been content to watch the goings-on from a distance. As the cliffs were not very high and the river not wide it was possible to obtain a good view of the nesting area without disturbing the birds.

An interesting coincidence observed during the extirpation of Peregrines from this Alberta river was the population expansion of the Prairie Falcon (Falco mexicanus). On the same 25-mile stretch three pairs of Prairie Falcons were breeding in 
1960. One of these sites was later deserted because of the building of a cabin on top of the cliff. But in 1965 a pair established itself on a site nearby which was formerly held by Peregrines. In 1966 another former Peregrine cliff was taken up, and the year after a male "Prairie" had annexed a third deserted Peregrine nesting site, while a pair of "Prairies" had returned to the site below the cabin. Territorial battles between Prairie Falcons were observed on several occasions. Twice there were two females and one male frequenting the same cliff in the early days of match-making.

In one instance mexicanus.. was quick in taking action. On April 17, 1966, there were three Prairie Falcons (one male and two females) plus one male Peregrine present ai a long cliff which for many years had been the territory of a pair of "blue falcons", according to a nearby farmer. That year the Peregrine's mate had apparently not turned up and the male was unable to drive off the intruders. It was an excellent opportunity to compare the powers of flight of the two kinds of falcons. The Peregrine proved vastly superior. The "Prairies" were put on the defensive. One of the females had several tail feathers missing, possibly knocked out by the attacker. When the Peregrine made one of his lightning swift passes mexicanus would turn over on its back and present its talons which the Peregrine avoided at a hair's breadth. When perched on the cliff "Prairies" were not safe from attack either. The Peregrine dived from above, often trying to surprise his victim by concealing his approach behind trees and rock outcrops. The threatened "Prairie" jumped up at the last moment and turned over on its back, stretching its legs like a baseball player reaching out to catch a high-flying ball. Of course actiors like these were not without risk for attacker and attacked alike. It was remarkable that the "Prairies" did not attack the Peregrine. Even the male "Prairie" completely ignored his presence. Falco mexicanus seemed to rely on patience and strength of numbers. A week later the Peregrine had disappeared, and two "Prairies" were firmly established at the cliff.

The observed local population increase of Falco mexicanus is probably a direct result of widespread clearing of the surrounding areas, which created more hunting territories, and of the availability of nesting sites formerly held by aggressive Peregrines. Reasons why the Prairie Falcons were not affected by the same evils that caused the elimination of the Peregrines, may be found in their different food habits and migratory wanderings. A comparison of the levels of pesticide residues would no doubt be interesting. Possibly also the fact that Prairie Falcons are not as eagerly sought after by falconers, at the nest as well as on migration, as Peregrines account for the continued breeding success of mexicanus. Obvicusiy one could suspect the Prairie Falcons of this area as having driven out the Peregrines. I have found no evidence to support this suspicion, in spite of the fact that the Prairie Falcons seem to arrive at the nesting site earlier than the Peregrines.

As Cade (1960) suggests, nesting sites are established by tradition. On this Alberta river certain cliffs were held by "Prairies" and others by Peregrines from year to year. The final disappearance of the Peregrines on this river (as well as on other. Alberta rivers) has been characterized by an apparent shortage of adult birds. Often only the male returned in spring. He could hold the cliff for many months chasing other raptors and corvids away, but seemed unable to attract a mate. The year after, such cliffs were vacant or held by one or two Prairie Falcons.

\section{LITERATURE CITED}

Broun, M. 1966. What future for birds of prey? Audubon, $68: 330-334$.

Cade, T. J. 1960. Ecology of the Peregrine and Gyrfalcon population in Alaska. Univ. California Publ. Zool., 63:151-290.

Cade, T. J., C. M. White, and J. R. Haugh. 1967. Peregrines and pesticides in Alaska. Raptor Research, 2 :23-38.

Herbert, R. A., and K. G. S. Herbert. 1965. Behavior of Peregrine Falcons in the New York City region. Auk, $82: 62-94$. 